\title{
Business strategies most frequently applied in companies in the municipality of Poza Rica, Veracruz
}

\section{Estrategias empresariales con mayor frecuencia de aplicación en empresas del Municipio de Poza Rica, Veracruz}

\author{
MARTÍNEZ-LEE, Maribel†*, SALAZAR-VIOLANTE, María Abigail, SARMIENTO-REYES, Celso \\ Ramón and GONZÁLEZ-RIVERA, Montserrat
}

Tecnológico Nacional de México/ Poza Rica. / Head of Business Management Engineering

ID $1^{\text {st }}$ Author: Maribel, Martínez-Lee / ORC ID: 0000-0002-3928-8967, CVU CONACYT ID: 578164

ID $1^{\text {st }}$ Co-author: María Abigail, Salazar-Violante / ORC ID: 0000-0002-6715-4595, CVU CONACYT ID: 480669

ID $2^{\text {nd }}$ Co-author: Celso Ramón, Sarmiento-Reyes / ORC ID: 0000-0002-5400-8062, CVU CONACYT ID: 35783

ID $3^{\text {rd }}$ Co-author: Montserrat, González-Rivera / ORC ID: 0000-0001-5657-5450

DOI: $10.35429 /$ JIO.2021.8.5.32.40

Received May 28, 2021; Accepted June 30, 2021

\begin{abstract}
This document presents the results obtained from the study conducted in order to know which were the most frequently applied strategies in the companies of Poza Rica, Veracruz, Mexico, to which a strategic plan was developed as part of academic projects carried out by students of the Business Management Engineering career, considering as axis the subject of Strategic Management of the academic program of the National Technology of Mexico with key AED-1035, during the years 2018, 2019 and 2020. The objective of the study is to identify the strategies that are most frequently presented, and in this way, help entrepreneurs to have a reference of the areas that are more susceptible to analyze in their companies. The study consisted of classifying the strategies by areas, based on the existing theoretical framework in this regard, resulting in that the strategies that appear most frequently are financial, marketing, processes and human resources, and some less frequent ones called others.
\end{abstract}

Functional areas, Strategies, Strategic management

\begin{abstract}
Resumen
El presente documento presenta los resultados obtenidos del estudio realizado con el fin de conocer cuáles fueron las estrategias aplicadas con mayor frecuencia en las empresas de Poza Rica, Veracruz, México, a las cuales se les desarrolló un plan estratégico como parte de proyectos académicos realizados por alumnos de la carrera de Ingeniería en Gestión Empresarial (IGE), considerando como eje la asignatura de Gestión estratégica del programa académico del Tecnológico Nacional de México con clave AED-1035, durante los años 2018, 2019 y 2020. El objetivo del estudio es identificar las estrategias que se presentan con mayor frecuencia, y de esta forma, coadyuvar a que los empresarios tengan una referencia de las áreas que son más susceptibles de analizar en sus empresas. El estudio consistió en clasificar las estrategias por áreas, con base en el marco teórico existente al respecto, dando como resultado que las estrategias que aparecen con mayor frecuencia son financieras, de mercadotecnia, de procesos y de recursos humanos, y algunas menos frecuentes denominadas como otras.
\end{abstract}

Áreas funcionales, Estrategias, Gestión estratégica

Citation: MARTÍNEZ-LEE, Maribel, SALAZAR-VIOLANTE, María Abigail, SARMIENTO-REYES, Celso Ramón and GONZÁLEZ-RIVERA, Montserrat. Business strategies most frequently applied in companies in the municipality of Poza Rica, Veracruz. Journal-Industrial Organization. 2021. 5-8: 32-40

*Correspondence to Author (maribel.martinez@itspozarica.edu.mx)

$\dagger$ Researcher contributing first author. 


\section{Introduction}

Strategy is a word used within companies, which has always been immersed in their daily work. The first definitions of strategy are focused on military operations, becoming involved in a general vision of command or leadership, taking relevance in the business environment since the early seventies due to social and cultural changes that impacted on trade.

These strategies are the result of gathering information about what exists within the company (in its various areas), what is outside it (government, technology, society, demographics, others) and where you want to go, that is, the vision that the company has; in this sense, the application of engineering techniques and tools for obtaining business strategies makes it possible to structure the company so that decision making is more reliable (Gallardo, 2012); unfortunately, this information is not always taken into account by entrepreneurs, either by ignorance or by considering that it is not necessary.

In the career of Business Management Engineering of the Instituto Tecnológico Superior de Poza Rica, the subject of Strategic Management is taught, which includes the necessary methodology to diagnose, analyze, establish, evaluate strategies, and make decisions to improve the areas of the companies. This allows linking the academic sector with the productive sector, applying the tools provided by this subject, to support companies in their analysis. Thus, several generations of students have resorted to the companies that exist in the municipality in which the educational institution is located, to diagnose their situation and based on that to design strategies for them, but it has been observed that entrepreneurs, do not know the application of techniques and tools to reduce their risks and also do not have a historical reference of the types of strategies that have been developed more frequently (if so) in the companies of Poza Rica, Ver.

This document is intended to provide information in that sense, which business strategies present the highest frequency to improve the various areas of the companies in the area, offering the ability to identify these areas of improvement decrease or eliminate unwanted situations in one's own business.
To do this, an analysis of the academic projects carried out in the period 2018-2020 was carried out, which is presented through tables and graphics to facilitate understanding.

\section{Justification}

Currently micro and small businesses in the city of Poza Rica, Veracruz, do not consider using techniques or tools to know their areas for improvement, this being a niche for students to take advantage of Business Management to develop academic projects focused on making a diagnosis and from this generate various strategies for improvement.

From the projects that have been developed in the last 3 years, very useful information was obtained for the city's businessmen. In this way, knowing which are the most frequently used strategies (resulting from the diagnoses of the academic projects), allows companies to focus their attention on these areas, thus foreseeing the solution of future problems. On the other hand, showing the methodology used by the institution has two objectives: first, to contribute to participate in the permanence and development of microenterprises and, secondly, to show a reference of the use of engineering techniques and tools in companies for the diagnosis of their situation.

\section{Problematic}

There are several businesses, micro and small companies in the region that do not have a control of the situation that prevails in them, these entities are exposed to a risk level in their operational areas, risks that can be financial, in their legal constitutions, and inherent in human resources, among others; therefore, they are susceptible to be affected, even to the extent of disappearing.

With this, it is possible to observe the lack of knowledge of the existence of techniques and tools that can be used to know the real situation of their businesses, as well as which are the strategies that are more frequently developed and implemented in the businesses or companies of their environment, being lacking of experiences to consider for the improvement of their business. 
It is important to note that the techniques and tools in the diagnosis of the real situation of a business or company have a considerable influence on the permanence and development of the same, so, given these circumstances, the need to analyze the results of the application of techniques and tools of Strategic Management in the projects that have developed students of Business Management Engineering during the last 3 years, and identify the strategies that appeared most frequently in these projects is detected. This analysis is presented through graphic and illustrative designs of the description of the strategies.

\section{Objective}

Identify the strategies designed and implemented more frequently as a result of the methodological application of Strategic Management in companies in the municipality of Poza Rica, Ver., from 2018 to 2020.

\section{Theoretical Framework}

Every company is made up of various departments, known as functional areas, which "are those that allow the proper functioning of the company [and that the] working together helps them to achieve the objectives set by the general direction of the organization" (Chao, n.d.); among the main ones we can distinguish: finance, marketing, production, and human resources.

The finance area is in charge of the correct administration of the financial resources that the company has, as well as the raising of funds so that it can carry out its operations. In short, "the financial function of the organization is to try to increase the shareholders' equity by obtaining modest funds and the proper management and investment in resources that generate economic gains" (Garza, 2000, as cited in Chao, n.d.). Also, Chao (n.d.) mentions that the marketing department is one of the most important within the company, because "it is responsible for identifying a need and satisfy it through a deep knowledge of the customer and seeks to ensure that the product or service is tailored to it". Regarding the production department, it is understood as "the one in charge of transforming inputs into finished products or services" (Chao, n.d.).
According to David (2003), the human resources area "includes activities such as recruitment, interviewing, appraisals, selection, orientation, orientation, training, development, care, evaluation, reward, discipline, promotion, transfer, demotion and dismissal of employees, as well as the management of union relations".

On the other hand, according to Gallardo (2012), every organization needs to define actions to achieve the structural process. This set of actions is known as strategies. Therefore, he defines strategy as "the selected process through which it's expected to achieve a future state". The main reason for companies to make use of its application is to have a better position in the market compared to its competitors, as well as to capture a greater number of customers.

In this way, Paris (2005) defines strategic planning as "the process by which an organization, once it has analyzed its environment in which it operates and set its medium and long-term objectives, chooses (selects) the most appropriate strategies to achieve those objectives and defines the projects to be implemented for the development of its strategies".

In this sense, Martinez et al. (2020) mention that strategic planning is essential in organizations, especially if they want to survive and succeed in these times of globalization, where technological advances grow every day with greater agility. This requires a high degree of preparation, skill and anticipation of the social needs of the same organization. These same authors present some of the advantages of strategic planning, such as:

- $\quad$ Anticipates the allocation of resources for the achievement of the determined objectives, facilitating decision making in the organization.

- Effectively applies human, financial, material, information and time resources.

- It detects in advance the opportunities and threats close to the organization.

- It specifies the basic factors that mark the success or failure of the company.

- Stimulates communication from the top management of the organization.

- It allows the evaluation, acceptance and rejection of action alternatives.

- It allows to take reference points for decision making. 
- It makes it easier to handle situations outside the company.

- Reduces uncertainty within the organization.

In addition, Martínez et al. (2020) point out that in order to carry out strategic planning it is first necessary to make a strategic analysis of the organization, which is the process that investigates and analyzes the internal and external environment of a company, in order to formulate strategies for decision making. The internal analysis consists of studying the different elements within a project or company, in order to know its situation. While the external analysis allows to objectively evaluate the external elements in order to better understand the environment in which the company operates; so it's precisely this external analysis that provides the advantage of detecting in advance the opportunities and threats close to the organization.

Gallardo (2012), points out that, from the information obtained from these two analyses, "It is necessary to discern which situation is critical for the company and what priorities exist according to the structural bases (mission, vision and values)". For this reason, Martinez et al. (2020) mention that for a better understanding of the results, it is necessary to synthesize the information obtained from tools known as portfolio techniques. These techniques for the analysis of competitiveness are made up of: the SWOT matrix, the BCG matrix and the McKinsey-GE matrix, which are explained below:

The SWOT matrix is an easy-to-use tool to obtain an overview of the strategic situation of a company. It has multiple applications and can be used by all levels of the corporation and in different units of analysis, such as product, market, product-market relationship, product line, corporation, division, strategic business unit, etc. (Gallardo, 2012).

The SWOT matrix allows to determine how competitive the company is and how capable it is to perform in the market. In this analysis, the first thing that is done is to classify the internal factors, which are strengths and weaknesses, and the external factors, which are opportunities and threats. Subsequently, those factors that should be included in the SWOT matrix are selected.
The strengths of an organization are those functions that are performed correctly, such as: certain skills and abilities of staff with certain psychological attributes and evidence of their competence. In contrast, a weakness is defined as a factor that makes the organization vulnerable or simply an activity that the company performs poorly.

Opportunities are those external environmental forces that represent potential elements of growth or improvement. Threats, on the other hand, represent the sum of environmental forces that are not controllable by the organization, but represent negative forces or aspects and potential problems.

The Growth - Participation matrix, created by the Boston Consulting Group (BCG) (hence it is known as BCG Matrix), is a tool that, according to Alcaide (1984), is based on the idea that businesses have different financial characteristics and can design different strategies according to their position of growth and competitiveness. The BCG matrix is formalized in a $2 \times 2$ structure, where the vertical axis represents the market growth rate and the horizontal axis represents the market share, as shown in the figure below:

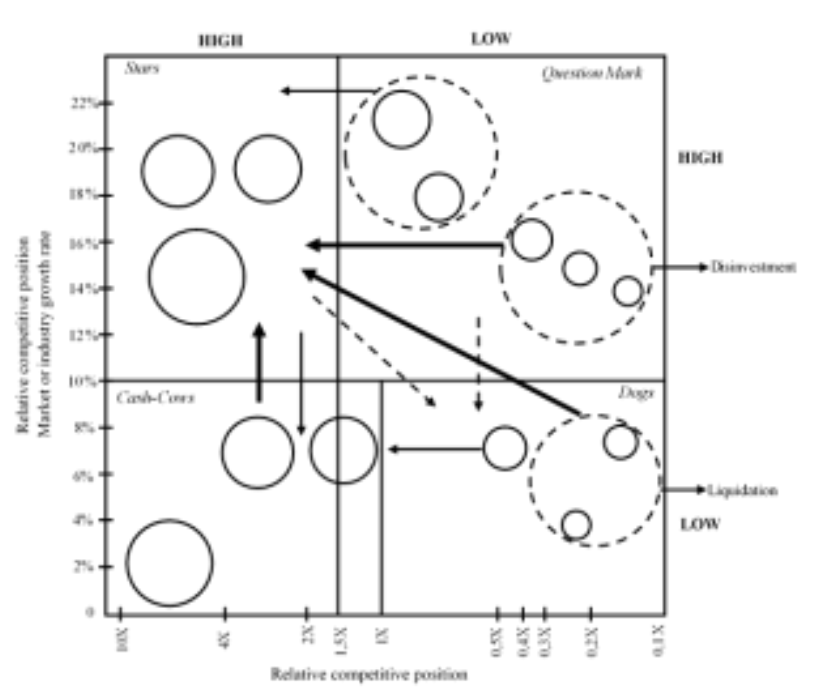

Figure 1 BCG Matrix

Source: Own elaboration, based on Alcaide (1984)

According to Alcaide (1984), the positions of a company can be:

- Stars: They seek to improve and/or defend their position in the market; their net cash-flow is close to zero or negative. - Question marks: Aggressive move to capitalize on growth opportunity or divestment. Negative net cash flow.

MARTÍNEZ-LEE, Maribel, SALAZAR-VIOLANTE, María Abigail, SARMIENTO-REYES, Celso Ramón and GONZÁLEZ-RIVERA, Montserrat. Business strategies most frequently applied in companies in the municipality of Poza Rica, Veracruz. Journal-Industrial Organization. 2021 
- Cash-cows: Maximize the generation of financial resources. Positive net cashflow.

- Dogs: Movements towards divestment or liquidation. Net cash-flow close to zero or negative.

Depending on the position of the company (or the product), strategies are implemented according to the situation.

Also, Gallardo (2012) mentions that the BCG matrix allows a multi-divisional organization to manage its business portfolio by analyzing the relative share of the market it is occupying and the industry growth rate of each of the organization's divisions. On the other hand, in the 70s of the twentieth century, the company General Electric requested support from the consulting firm McKinsey to analyze the situation at that time, since its sales were growing, but did not provide the expected return.

From the BCG matrix, McKinsey elaborates its own matrix (known as the attractiveness-competitiveness matrix, McKinsey Matrix or General Electric Matrix) that provides more information, by using several indicators to evaluate the dimensions, which are: strength of the studied business and attractiveness of the industry, both with 3 possible levels (high, medium and low). The strength of the market (competitiveness) is placed on the horizontal axis and the attractiveness of the industry (or market) is placed on the vertical axis, as shown in the following figure:

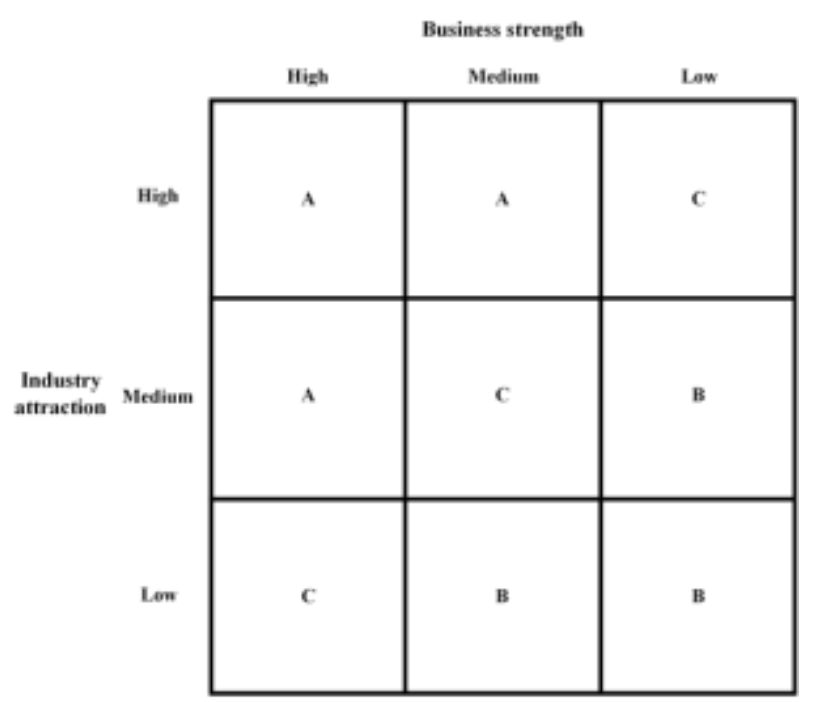

Figure 2 GE-McKinsey Matrix

Source: Own elaboration, based on Alcaide (1984)
As can be seen in the figure, in the lower right corner there is a low market attractiveness and low business strength or competitiveness, which could lead to a decision to disinvest.

On the other hand, a high attractiveness but low competitiveness (upper right corner), advises selective development, that is, investing resources only if the opportunities compensate. On the other hand, a low market attractiveness but high competitiveness (lower left corner) implies having to maintain market positioning but without the need for large investments.

Finally, the ideal situation is when the market attractiveness is high and at the same time a high competitiveness is maintained (upper left corner), which allows to implement an offensive strategy in which resources must be invested to grow.

The rest of the areas that make up the matrix correspond to products for which the positioning is undefined.

\section{Methodology}

The present research was conducted under a quantitative approach, by means of a descriptive and statistical study of transversal cohort studying the integrative projects developed by three generations of the career of Business Management Engineering $(2018,2019,2020)$ of the Instituto Tecnológico Superior de Poza Rica, which carried out such projects having as axis subject Strategic Management of the academic program of the Tecnológico Nacional de México with key AED-1035.

As part of the first stage, we began with the review of the academic projects carried out by the students of the three years, from which we obtained the total number of companies and the total number of strategies. In the second stage the classification of the strategies resulting from the diagnoses was made, the classification is considered in the areas of finance, marketing, processes, human resources and others, the latter are those that have little frequency, finally it is schematized with statistical tools and the analysis is presented. 


\section{Results}

The methodology applied by the students of the Business Management Engineering career, in the integrative projects having as axis subject Strategic Management consisted in the development of a diagnosis with the application of techniques such as: EFE (external factors evaluation) matrix, IFE (internal factors evaluation) matrix, Systemic analysis matrix, also known as influence matrix (internal analysis factors), Impact-probability matrix (external analysis factors).

We proceeded to the phase of analysis of the results and applied the matrices for setting strategic objectives such as: SPACE Matrix (Formulation of objectives using the SWOT matrix, BCG Matrix, McKinsey-GE Matrix) thus obtaining the strategies that companies should apply to improve their areas, such as finance, marketing, administrative, human resources, processes and operational, among others.

At the end of the academic projects that were applied between the years 2018-2020, the concrete information of the strategies of various companies was obtained, as explained below.

Table 1 provides information on the total number of companies in which the students of the Business Management course carried out academic projects resulting in different strategies.

\begin{tabular}{|c|r|r|}
\hline Year & Companies & Strategies \\
\hline 2018 & 16 & 92 \\
\hline 2019 & 24 & 99 \\
\hline 2020 & 19 & 84 \\
\hline Total & 59 & 275 \\
\hline
\end{tabular}

Table 1 Total number of participating companies and strategies obtained in the development of integrative projects in the years 2018-2020

Source: Own elaboration, with information from the projects

With this it can be seen that in these three years being analyzed there was the participation of 59 companies, being the year 2019 where there was the largest number of companies, representing $41 \%$ total of the participating companies, and a total of 275 strategies were obtained, being likewise the year 2019 where there was the largest number of strategies, representing $36 \%$ of all strategies generated, as shown in graphics 1 and 2.

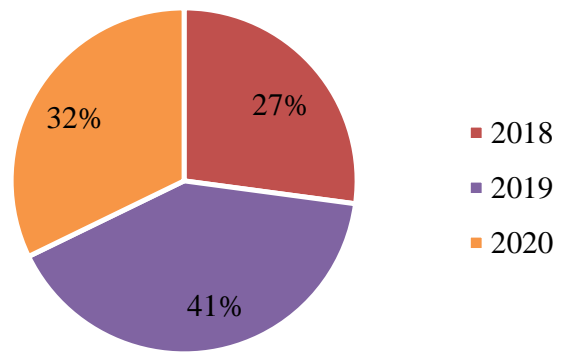

Graphic 1 Companies participating in Integrating Projects during the years 2018-2020

Source: Own Elaboration, with information from the projects

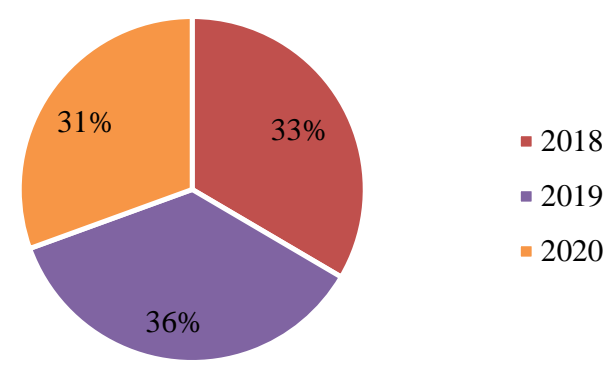

Graphic 2 Strategies developed in Integrating Projects during the years 2018-2020

Source: Own Elaboration, with information from the projects

Subsequently, the strategies for each year were classified according to the theory presented by Gallardo (2012) in the following areas:
a. Finance.
b. Marketing.
c. Production.
d. Human resources.
e. Other (administrative, legal, customer service, etc.).

Table 2 contains the 2018 strategy ranking information.

\begin{tabular}{|l|r|}
\hline \multicolumn{2}{|c|}{ Year 2018 } \\
\hline Types of strategies & Quantity \\
\hline Finance & 20 \\
\hline Marketing & 27 \\
\hline Production & 25 \\
\hline Human Resources & 10 \\
\hline $\begin{array}{l}\text { Other (administrative, legal, customer } \\
\text { service, etc.) }\end{array}$ & 10 \\
\hline
\end{tabular}

Table 2 Ranking of strategies obtained in 2018 Source: Own Elaboration, with information from the projects

Also, Graphic 3 shows the percentage frequency of strategies in 2018. 


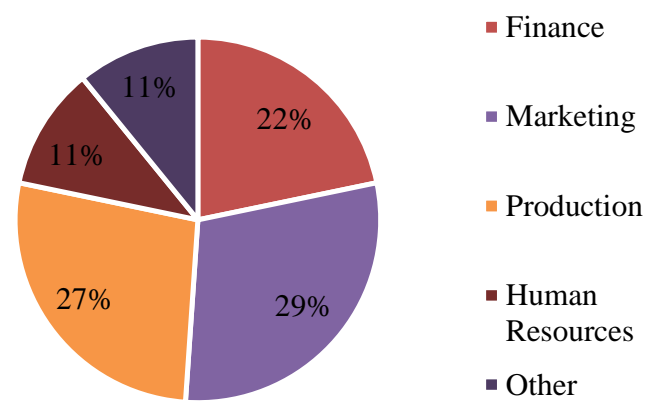

Graphic 3 Percentage frequency of each type of strategy in 2018

Source: Own Elaboration, with information from the projects

Based on the table and graphic above, it can be seen that the type of strategy that had the highest frequency this year was marketing with a total of 27 strategies, representing $29 \%$, followed by production, which had a total of 21 strategies, representing $27 \%$.

Table 3 contains the 2019 strategy ranking information.

\begin{tabular}{|l|r|}
\hline \multicolumn{2}{|c|}{ Year 2019 } \\
\hline Types of strategies & Quantity \\
\hline Finance & 26 \\
\hline Marketing & 13 \\
\hline Production & 34 \\
\hline Human Resources & 15 \\
\hline $\begin{array}{l}\text { Other (administrative, legal, customer } \\
\text { service, etc.) }\end{array}$ & 11 \\
\hline
\end{tabular}

Table 3 Ranking of strategies obtained in 2019

Source: Own elaboration, with information from the projects

Also, Graphic 4 shows the percentage frequency of the strategies in 2019.

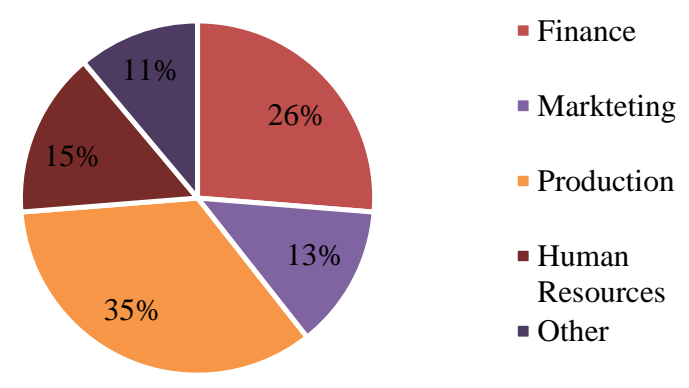

Graphic 4 Percentage frequency of each type of strategy in 2019

Source: Own Elaboration, with information from the projects
Based on the table and graphic above, it can be seen that the type of strategy that had the highest frequency this year was production with a total of 34 strategies, representing 35\%; followed by finance, which had a total of 26 strategies, representing 26\%. Table 4 contains the 2020 strategy ranking information.

\begin{tabular}{|l|r|}
\hline \multicolumn{1}{|c|}{ Year 2020 } & Quantity \\
\hline Types of strategies & 18 \\
\hline Finance & 25 \\
\hline Marketing & 25 \\
\hline Production & 6 \\
\hline Human Resources & 10 \\
\hline $\begin{array}{l}\text { Other (administrative, legal, customer } \\
\text { service, etc.) }\end{array}$ & \\
\hline
\end{tabular}

Table 4 Ranking of strategies obtained in 2020

Source: Own Elaboration, with information from the projects

Also, Graphic 5 show the percentage frequency of the strategies in 2020 .

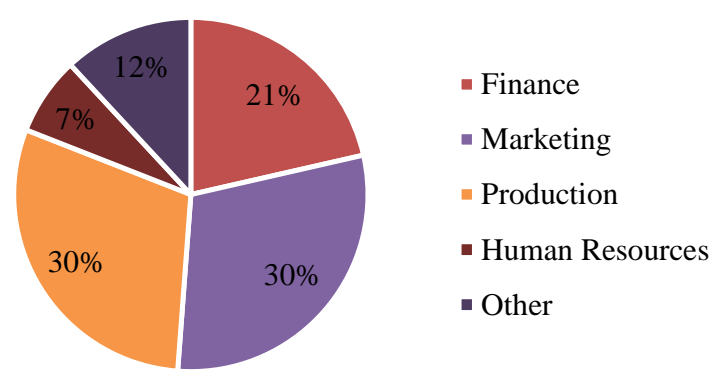

Graphic 5 Percentage frequency of each type of strategy in 2020

Source: Own elaboration, with information from the projects

Based on the table and graphic above, it can be seen that the types of strategies that had the highest frequency this year were marketing and production, with 25 strategies respectively, representing $30 \%$ each; followed by finance, which had a total of 18 strategies, representing $21 \%$.

From these data, the percentage distribution of the strategies obtained in each year was analyzed, as shown in Graphic 6, in order to be able to observe more clearly the difference between the number of strategies of each type that were developed each year. 


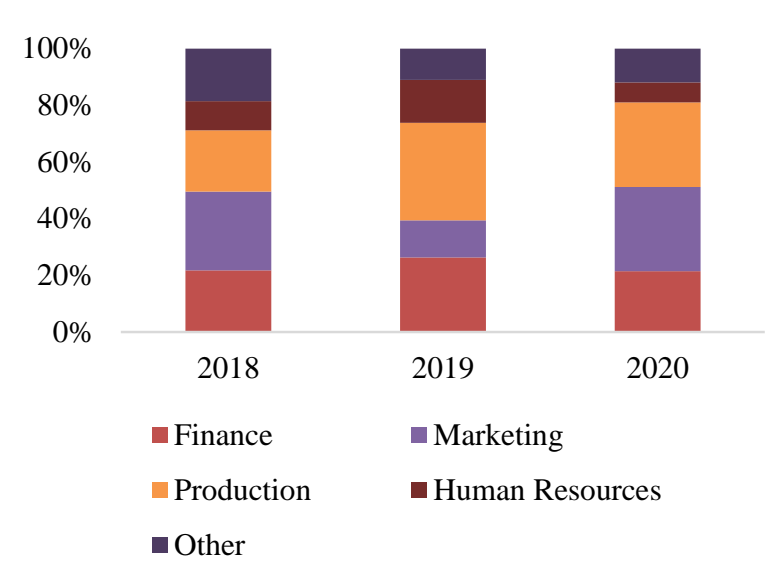

Graphic 6 Percentage distribution of the strategies developed in Integrating Projects during the years 20182020

Source: Own Elaboration, with information from the projects

Finally, Table 5 shows the total number of strategies generated by each type during the three years covered by this study.

\begin{tabular}{|l|r|}
\hline \multicolumn{2}{|c|}{ Years 2018-2020 } \\
\hline Types of strategies & Quantity \\
\hline Finance & 64 \\
\hline Marketing & 65 \\
\hline Production & 84 \\
\hline Human Resources & 31 \\
\hline $\begin{array}{l}\text { Other (administrative, legal, customer } \\
\text { service, etc.) }\end{array}$ & 31 \\
\hline
\end{tabular}

Table 5 Ranking of strategies obtained in the years 20182020

Source: Own Elaboration, with information from the projects

Also, Graphic 7 shows the percentage frequency of strategies during the years 20182020.

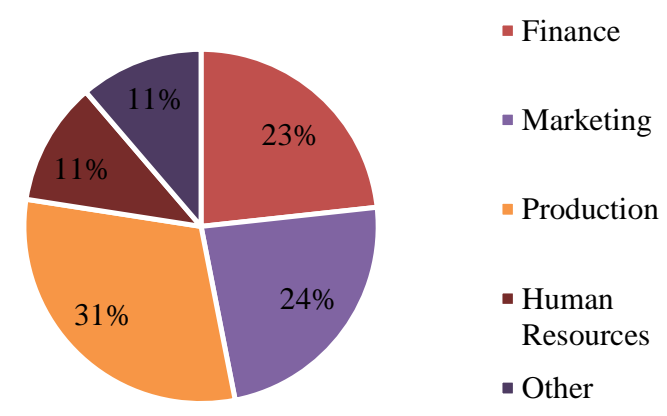

Graphic 7 Percentage frequency of each type of strategy in the years 2018-2020

Source: Own Elaboration, with information from the projects
Based on the table and graphic above, it can be seen that the type of strategies that had the highest frequency during the three years was production, with a total of 84 strategies, representing $31 \%$; followed by marketing, which had a total of 65 strategies, representing $24 \%$.

On the other hand, according to the order of priority of the strategies, they can be classified as follows:

\author{
1. Production. \\ 2. Finance. \\ 3. Marketing. \\ 4. Human resources. \\ 5. Other (administrative, legal, customer \\ service, etc.).
}

This classification was made based on previous knowledge and experience, as well as those acquired during the development of these projects; taking as a starting point that by improving the production area of a company, the rest of the areas are also favored, so this is considered as the area that should be given higher priority when developing strategies within a strategic plan.

\section{Conclusions}

As a starting point it is identified that the companies of Poza Rica should pay more attention to the processes in their production area, because this is the area where more strategies arise as a result of the diagnostics and analysis carried out with the methodology of the study program of Strategic Management during the development of academic projects, that is, the production areas of the various companies studied are generally not planned or organized, which is why when making a diagnosis with the methodology of strategic management, they are detected as areas of opportunity to carry out improvements through various strategies.

These strategies are aimed at optimizing the production processes of the companies, using tools and philosophies such as just in time, kanban, inventory control, $5 \mathrm{~S}$, etc., in order to achieve production efficiency, taking advantage of the time and resources available. 
On the other hand, Marketing is the area that has 24\%, followed by Finance with $23 \%$ and Human Resources with $11 \%$ of the $100 \%$ that make up the strategies. Specifically, marketing strategies focus on market growth using population forecasts and advertising resources, while finance strategies refer to establishing a solid financial situation, based on sales growth, cost savings, improving profits and forecasting the company's economy, and human resources strategies impact on service and customer treatment through attitudes that are achieved with training and job analysis.

Definitely, the identification of the strategies that most frequently arise when companies are diagnosed and analyzed, is a reference for entrepreneurs in the municipality of Poza Rica, that although it is true that all companies have different characteristics, consequently it originates to fix their attention on those areas that are identified in the companies of their environment, which can be extremely useful to prevent the development of problems in the future. In other words, we can conclude that regardless of the line of business and size of the company, Strategic Management is essential to support its permanence and development.

\section{Acknowledgments}

To the Tecnológico Nacional de México, as well as to the Instituto Tecnológico Superior de Poza Rica, for giving us the opportunity to carry out this research and allowing us to use the information presented here. In addition, we thank all the businessmen of the municipality of Poza Rica, Veracruz, who opened the doors of their businesses to the students of the Business Management Engineering program so that they could develop these academic projects. Finally, to the teachers and all the staff of the institution for always being a guide for the students in the fulfillment of their activities and, above all, in the development of their professional competencies.

\section{References}

Alcaide, M. (1984). El concepto de estrategia y las matrices de 'portfolio'. Revista española de financiación y contabilidad, 13(45), 451-524. https://dialnet.unirioja.es/servlet/articulo?codig $\mathrm{o}=2481642$

Chao, M. (s.f.). Áreas funcionales de la empresa. Universidad Virtual del Estado de Guanajuato (UVEG).

http://accioneduca.org/admin/archivos/clases/m aterial/areas-funcionales-de-una-

empresa_1563561021.pdf

David, F. (2003). (9 $9^{\text {a }}$ ed.). Conceptos de Administración Estratégica. Edo. de México: Pearson Educación.

Gallardo, J. (2012). (1 ${ }^{\mathrm{a}}$ ed.). Administración Estratégica: De la visión a la ejecución. México D.F.: Alfaomega Grupo Editor.

Martínez, M., Salazar, M., Toledano, I., \& González, E. (2020). Participación de las mujeres estudiantes de Ingeniería en Gestión Empresarial del Tecnológico Nacional de México/ Poza Rica, Ver., en propuestas estratégicas de microempresas. En Handbook TVI CIERMMI Mujeres en la Ciencia Sociedad, violencia de género (pp. 50-65). ECORFAN. https://www.ecorfan.org/handbooks/Handbooks _Mujeres_en_la_Ciencia_TVI/Handbooks_Muj eres_en_la_Ciencia_TVI.pdf

París, F. (2005). (4 ${ }^{\mathrm{a}}$ ed.). La Planificación Estratégica en las Organizaciones Deportivas. Barcelona: Editorial Paidotribo. 